\title{
Alpha Particle Track Detection with Celluloid Films
}

\author{
H. Hasegawa, M. Matsuo, K. Yamakoshi and K. Yamawaki* \\ Department of Physics, Faculty of Science, Kyoto University, \\ Kitashirakawa-oiwake-cho, Sakyo-ku, Kyoto
}

Received July 1, 1968

\begin{abstract}
The solid state track detector of celluloid films (cellulose nitrate+camphor $25 \%$ in werght) using etching technique is suitable for low energy alpha particle detection. The critical rate of energy loss for track formation in celluloid films is determined as $1.3 \mathrm{MeV} / \mathrm{mg} \cdot{ }^{\circ} \mathrm{cm}^{2}$. Irradiated samples are etched in $\mathrm{NaOH}(6 N)$ solution at $46^{\circ} \mathrm{C}$ for 10 minutes. The etched tracks are observed under a view of optical microscope at magnification of $7 \times 20 \sim 7 \times 40$. Under vacuum condition of $10^{-3}$ Torr or at low temperature of $-26^{\circ} \mathrm{C}$ no changes are observed in track formation. The feature of track fading phenomena is different in hot water and air circumstances.
\end{abstract}

\section{Introduction}

The solid state track detectors using etching techniques are developed and extended rapidly by many investigators since $1962 .{ }^{1)}$

These detectors are suitable for heavy particle detections. Among them dielectric detectors of cellulose compounds are also available for investigations of radioisotopes of alpha particle emission, because the lightest detectable limit of cellulose nitrate is $\mathrm{He}$ ion particles $^{2 \sim 5)}$.

In this study, various properties of alpha track registration in celluloid films**) (cellulose nitrate + camphor $25 \%$ in weight) are investigated. The radioisotope Am-241 (alpha; 5.4 5.5 $\mathrm{MeV}$, intensity of $3 \times 10^{4} \mathrm{dpm}$ ) of package type is used as an alpha source. Irradiated samples are etched in $\mathrm{NaOH}$ solution and the etched tracks are observed under a view of optical microscope at magnification of $7 \times 20 \sim 7 \times 40$.

The diameter and depth of the etched tracks are 2 to 3 and 6 to 7 microns, respectively.

\section{Etching Conditions of Celluloid Films}

The irradiated celluloid films are etched in $\mathrm{NaOH}(6 N)$ solution. Experimental relations of solution temperature and etching time are examined. When the solution temperature is kept at $46^{\circ} \mathrm{C}$, various etching times are ex- amined for the purpose of clear track formation. The time of ten minutes is most suitable to make clear tracks in celluloid films. Under this etching condition the celluloid film is etched out by ca. 1 micron in thickness from upper and lower surfaces. The relation of the lost mass, which is taken off in etching operation, and etching time is examined and shown in Fig. 1. As shown above, at $46^{\circ} \mathrm{C}$ the optimum etching time is $10 \mathrm{~min}$, thus at $36^{\circ} \mathrm{C}$ and $26^{\circ} \mathrm{C}$ the optimum etching times are ca.

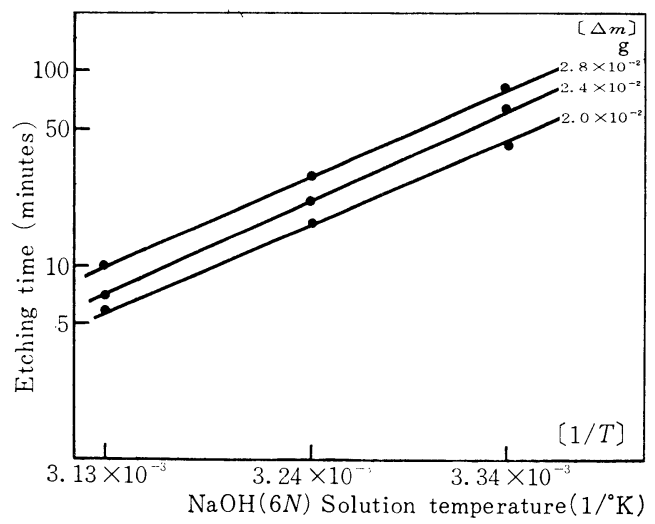

Fig. 1 Lost mass celluloid film $\left(100 \mathrm{~cm}^{2}\right)$.

* Present address: Department of Gyro, Japan Aviation Flectronics Industry, Ltd.

** Daicel Co. Ltd., Osaka, Japan. Film thickness: 100 microns, density: 1.32, molecular formula: cellulose nitrate $\mathrm{C}_{12} \mathrm{H}_{6} \mathrm{O}_{18} \mathrm{~N}_{4}$, camphor $\mathrm{C}_{10} \mathrm{H}_{16} \mathrm{O}$. 
30 and $80 \mathrm{~min}$, respectively.

As shown in Fig. 1 the relation of temperature and etching time is consistent with the formula in the temperature range from $20^{\circ} \mathrm{C}$ to $50^{\circ} \mathrm{C}$ :

$$
t=C \exp \left(\frac{U}{k T}\right)
$$

where $t$ and $T$ are etching time and solution temperature in Kelvin, respectively, $C$ and $U$ are constants and $k$ is the Boltzmann's constant.

In the optimum condition the constants $C$, $U$ are estimated as $6.03 \times 10^{-13} \mathrm{~min}$ and 0.838 $\mathrm{eV}$, respectively.

\section{Critical Rate of Energy Loss for Track Formation in Celluloid Films}

The critical rate of energy loss for track formation in celluloid films is determined by a simple method. A thin film absorber* is placed between the alpha source $\left({ }^{241} \mathrm{Am}\right)$ and a detector film. The experiment is carried out under a vacuum of $10^{-3}$ Torr.

The tracks on the celluloid film are counted and the results are shown in Fig. 2.

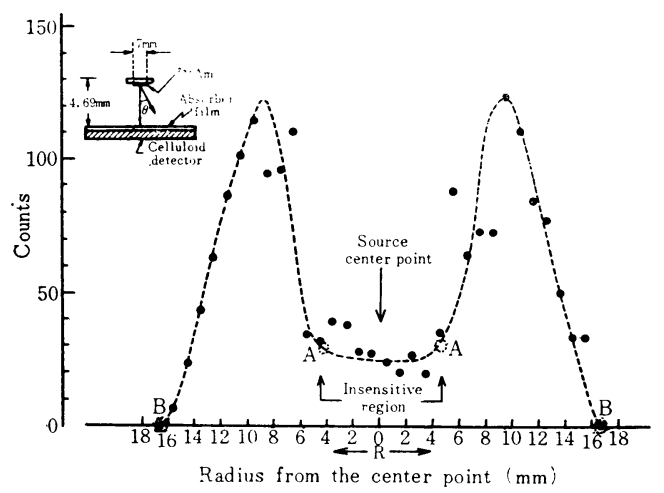

Fig. 2 Determination of the critical rate of energy loss for track formation in celluloid films.

The distance from the alpha source to the detector film is $4.69 \mathrm{~mm}$ and the diameter of the source disc is $7.0 \mathrm{~mm}$. The alpha particles with a small emission angle are slowed down by the absorber film not so sufficiently to register tracks in the celluloid film.

As shown in Fig. 2, the region of two peaks $(4.5 \leqq R \leqq 16.5 \mathrm{~mm})$ corresponds to the suitable energies of alpha particles for track formation in celluloid films. The positions of $A$ and $B$ correspond to the energies of alpha particles after absorber passages of more than 19.8 and 29.4 microns respectively. Thus the suitable residual energy of alpha particles for track formation remains between $2.6 \mathrm{MeV}$ and nearly zero. In the circle with radius of $4.5 \mathrm{~mm}$, number of the tracks does not become zero. These tracks may be brought from scattering process of alpha particles with edges of the source case or absorber holder and/or selfabsorption in the source material.

The critical rate of energy loss $\left(\frac{d E}{d X}\right)_{c}$ for track registration is determined as $1.3 \mathrm{MeV}$ $/ \mathrm{mg} \cdot \mathrm{cm}^{2}$ after calculations using the Bethe's formula ${ }^{6}$, where the used values of the mean excitation energy and the mean atomic number of celluloid are $70.5 \mathrm{eV}$ and 4.76 , respectively. The curve, shown in Fig. 3, gives the calculated rate of energy loss of alpha particle in celluloid films as a function of the energy per nucleon.

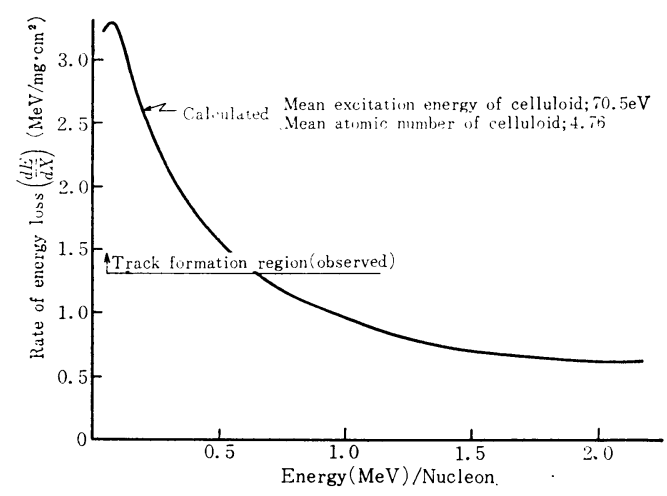

Fig. 3 The critical rate of energy loss for track formation in celluloid films.

The method described in this section is simple and conventional for determination of $\left(\frac{d E}{d X}\right)_{c}$ in detector films of various materials.

\section{Track Registration in Various Circumstances}

Under vacuum conditions of $10^{-2} \sim 10^{-3}$ Torr

* "Saran-Wrap" (Polyester film); $10.0 \pm 0.7$
(microns) in thickness and $1.7\left(\mathrm{~g} / \mathrm{cm}^{3}\right)$ in
density.


and at a low temperature of $-26^{\circ} \mathrm{C}$ no changes are observed in track formation of celluloid films in contrast with the tracks under $1 \mathrm{~atm}$ and at room temperature.

After exposure of celluloid films to ultraviolet radiation* with wave length of $2537 \AA$ $(4.95 \mathrm{eV})$, the films are irradiated by alpha flux for a long time. In this case incomplete or no tracks are observed. Furthermore, something like gas bubbles are observed in film surface layers, which suggests degradation of celluloid by ultra-violet radiation.

\section{Fading Effects of Temperature and Ultra-Violet Radiations}

\subsection{Temperature effects}

In order to investigate the temperature effects**) on track registration in celluloid films, the irradiated films are poured in hot water.

After that process, the films are etched in $\mathrm{NaOH}(6 N)$ at $46^{\circ} \mathrm{C}$ for ten minutes. And then the residual number of tracks is observed and counted under a view of optical microscope. The results are shown in Fig. $4 \mathrm{~A}$ and 4B. The fading time is 80 and 100 minutes in hot water at $79 \pm 0.5^{\circ} \mathrm{C}$ and $76 \pm 0.5^{\circ} \mathrm{C}$, respectively. At $86^{\circ} \mathrm{C}$ no tracks are observed after heating of less than 3 minutes. These temperatures exceed the softening point of celluloid films $\left(70 \pm 5^{\circ} \mathrm{C}\right)$.

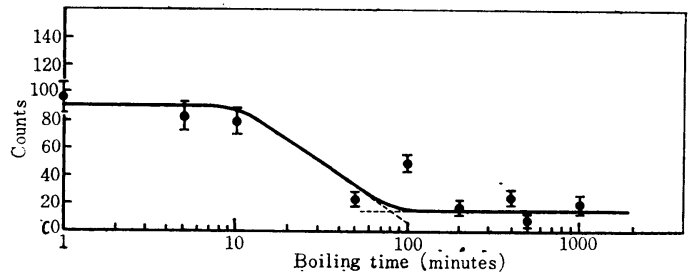

Fig. $4 \mathrm{~A}$ Track fading at $79 \pm 0.5^{\circ} \mathrm{C}$.

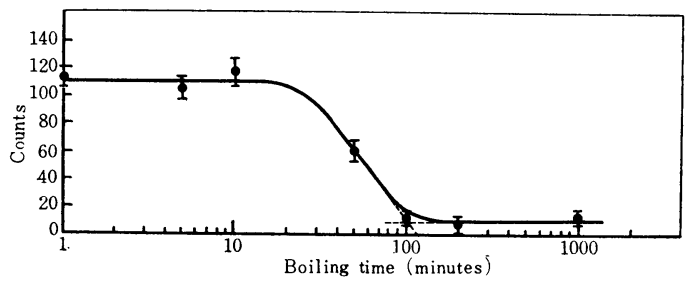

Fig. 4B Track fading at $76 \pm 0.5^{\circ} \mathrm{C}$.

The fading time $t_{f}$ is given by the relation;

$$
t_{f}=C_{f} \exp \left(\frac{U_{f}}{k T_{f}}\right) \text {. }
$$

The constants $C_{f}$ and $U_{f}$ are estimated as 0.63 $\times 10^{-89}$ minutes and $6.33 \mathrm{eV}$ respectively from the data at $79^{\circ} \mathrm{C}$ and $76^{\circ} \mathrm{C}$.

Extrapolation of this relation to room temperature $\left(23^{\circ} \mathrm{C}\right)$ suggests that tracks could last $0.36 \times 10^{13}$ years. The appearance of the residual tracks has no difference from the ordinary ones.

The feature of the fading effects is different in circumstances. In dry air, no fading effects are observed in irradiated celluloid films heated for 1000 minutes at $76^{\circ} \mathrm{C}$. This fact suggests many problems of track fading phenomena in celluloid films.

5.2. Ultra-violet radiation effects

The tracks made by irradiation of alpha particles in celluloid films are also faded by ultra-violet radiation.

An ultra-violet light lamp with wave length of $2537 \AA(4.95 \mathrm{eV})$ is used as a radiation source. At the sample position the photon flux is $1.23 \times 10^{18}$ photons $/ \mathrm{sec} \cdot \mathrm{cm}^{2}$. Irradiated celluloid films are exposed to ultra-violet radiation at the position for $0,10,20$ and 30 minutes. After etching process the residual tracks are counted. The results are shown in Table 1 .

Table 1 Fading effects due to ultra-violet radiations

\begin{tabular}{c|c|c}
\hline $\begin{array}{c}\text { Exposure time } \\
\text { (min) }\end{array}$ & $\begin{array}{c}\text { Counts } \\
\text { (in the area } \\
\left.\text { of } 1 \mathrm{~mm}^{2}\right)\end{array}$ & Faded tracks \\
\hline 0 & 82 & - \\
10 & 70 & 12 \\
20 & 56 & 26 \\
30 & 42 & 40 \\
\hline
\end{tabular}

The number of the residual tracks is decreased as the exposure time is increased. And the tracks after exposure process are expanded spherically. In Fig. 5A the ordinary tracks (exposure time is zero) and Fig. 5B the residual tracks (exposure time is $20 \mathrm{~min}$ ) are shown. The two pictures have been taken under the same conditions in the density of alpha

* For instance, at the position of ultra-violet radiation intensity of $1.23 \times 10^{18}$ photons $/ \mathrm{sec} \cdot \mathrm{cm}^{2}$ the exposure of fresh celluloid films are carried out for 45 minutes.

** Coefficient of linear expansion; $8 \sim 12 \times 10^{-5}$ ${ }^{\circ} \mathrm{C}$ (After ASTM D.696 Method) 
particle irradiation, etching process and magnification of optical microscope.

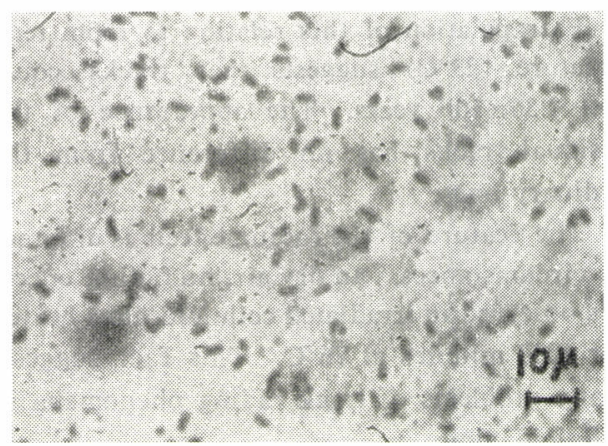

Fig. 5A The ordinary tracks (exposure time is zero) (magnification: $7 \times 90$ )

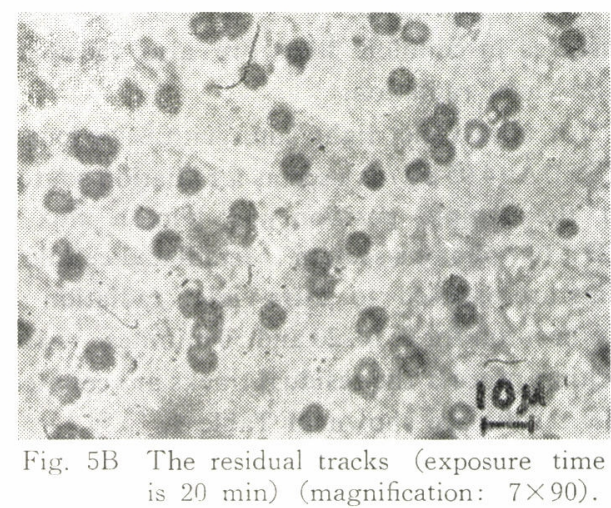

\section{Discussions and Conclusions}

The celluloid film detector is one of the most simple and uncomplicated ones. It is suitable for low energy alpha particle detection or energy discrimination, putting thin absorber films (ex. "Saran-Wrap") between radioactive sources and detector films. Several features of celluloid film detectors make them also available for autoradiography, "micro-map" representations of concentrated regions of $U$ and $\mathrm{Th}$ on mineral specimen surfaces or large area detectors of heavy components in primary cosmic rays, etc.

The features of track formation and fading in celluloid films suggest many problems. Among them, different feature of fading effects in hot water and air circumstances is interesting.

\section{References}

1) R.L. Fleischer, P.B. Price, R.M. Walker: Ann. Rev. Nucl. Sci., 13, 1 (1965)

2) R.L. Eleischer, P.B. Price, R.M. Walker: Rev. Sci. Instr., 37, 525 (1966)

3) R.C.Filz, et al.: General Electric Report 66-C-425 (1966)

4) R.L. Fleischer, et al.: Phys. Rev., 156, 353 (1967)

5) E.V. Benton, M.M. Collver: Health Physics, 13, 495 (1967)

6) H.A. Bethe: Zeits. f. Phys., 76, 293 (1938)

\title{
セルロイドフィルムによるアルファ粒子の飛跡検出
}

\author{
長谷川博一, 松尾光郎, 山越和雄, 山脇功次 \\ 京都大学理学部物理第二教室
}

\begin{abstract}
固体飛跡検出器としてセルロイドフィルム（硝化綿十 $25 \%$ 樟脳）の低エネルギー $\alpha$ 粒子に対する 種々の特性について報告する。 ${ }^{241} \mathrm{Am}$ の $5.5 \mathrm{MeV}$ の $\alpha$ 粒子をポリエステルフィルムを吸收剤とし て隇速し, 飛跡の記憶条件について調べた。飛跡はェッチングしてから，光学顕微鏡で観察する。 最適エッチング条件は，6規定 $46^{\circ} \mathrm{C}$ のカ性ソーダ中で 10 分間である。飛跡直径はェッチング後，

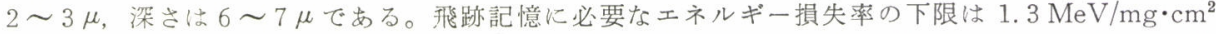

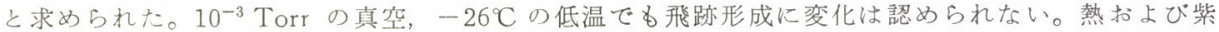
外線によるfading 現象についても與味ある事実が得られた。
\end{abstract}

